"The role of financial inclusion in financial stability: lesson from Jordan"

\begin{tabular}{|c|c|}
\hline AUTHORS & Mohammad O. Al-Smadi iD https://orcid.org/0000-0002-5100-7910 \\
\hline ARTICLE INFO & $\begin{array}{l}\text { Mohammad O. Al-Smadi (2018). The role of financial inclusion in financial } \\
\text { stability: lesson from Jordan. Banks and Bank Systems, 13(4), 31-39. } \\
\text { doi:10.21511/bbs.13(4).2018.03 }\end{array}$ \\
\hline DOI & http://dx.doi.org/10.21511/bbs.13(4).2018.03 \\
\hline RELEASED ON & Monday, 12 November 2018 \\
\hline RECEIVED ON & Monday, 15 October 2018 \\
\hline ACCEPTED ON & Monday, 05 November 2018 \\
\hline LICENSE & $\begin{array}{l}(\boldsymbol{( c )} \overline{\mathrm{EY}} \\
\text { This work is licensed under a Creative Commons Attribution } 4.0 \text { International } \\
\text { License }\end{array}$ \\
\hline JOURNAL & "Banks and Bank Systems" \\
\hline ISSN PRINT & $1816-7403$ \\
\hline ISSN ONLINE & $1991-7074$ \\
\hline PUBLISHER & LLC "Consulting Publishing Company "Business Perspectives" \\
\hline FOUNDER & LLC "Consulting Publishing Company "Business Perspectives" \\
\hline & $\begin{array}{l}\text { ニE } \\
\text { =E }\end{array}$ \\
\hline NUMBER OF REFERENCES & NUMBER OF FIGURES \\
\hline 22 & 0 \\
\hline
\end{tabular}

C The author(s) 2022. This publication is an open access article. 


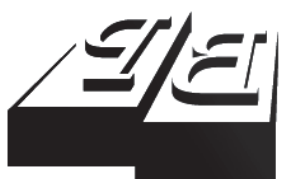

BUSINESS PERSPECTIVES

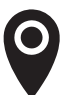

LLC "CPC "Business Perspectives" Hryhorii Skovoroda lane, 10, Sumy, 40022, Ukraine

www.businessperspectives.org

Received on: $15^{\text {th }}$ of October, 2018 Accepted on: $5^{\text {th }}$ of November, 2018

(C) Mohammad O. Al-Smadi, 2018

Mohammad O. Al-Smadi, Assistant Professor, Department of Finance and Banking, Faculty of Business, Philadelphia University, Amman, Jordan.

\title{
THE ROLE OF FINANCIAL INCLUSION IN FINANCIAL STABILITY: LESSON FROM JORDAN
}

\begin{abstract}
This study aims to examine the relationship between financial inclusion and financial stability in Jordan by using Fully Modified Least Squares (FMOLS) technique. The analysis is based on time series from 2006 to 2017. Jordanian financial inclusion index is developed to assess the level of financial inclusion, whereas financial stability was measured by Jordanian financial stability index proposed by Central Bank of Jordan. The results show a weak significant and positive impact of financial inclusion on the financial stability in Jordan. Additionally, five control variables are used in the study. The results show a negative impact of domestic credit to private sector, income inequality, financial integration, and global financial crisis on financial stability. In contrast, real GDP per capita has a significant and positive impact. It is expected that the findings of the study can be used by policy makers and supervising authorities to realize the objectives of the national strategy of financial inclusion in Jordan.
\end{abstract}

Keywords

\section{JEL Classification G21, G28}

\section{INTRODUCTION}

Access to and use of financial services is considered an important factor in accelerating sustainable economic and social growth, reducing poverty and unemployment, and enhancing the stability of the financial sector (Zins \& Weill, 2016). Inability to obtain finance affects economic growth and poverty negatively. This is due to the idea that the lack of funds' access prevents the poor from saving and investing in income generating enterprises. In contrast, easy access of finance encourages enterprises to invest more, accept more risk and thus, stimulate economic growth (Neaime \& Gaysset, 2018). After the recent financial crisis, the world's interest in facilitating the use of financial services by all segments of society has increased. Hence, international organizations in addition to the financial and monetary authorities in both developed and developing countries have adopted the concept of Financial Inclusion (FI) as a priority within their strategies and policies in order to achieve comprehensive and sustainable growth (Rasheed, Law, Chin, \& Habibullah, 2016; Siddik, Alam, \& Kabiraj, 2018). J.-H. Kim (2016) summarized the reasons behind financial exclusion, which are the following. First, the reluctance of financial institutions to deal with some customers because of their low income and high risk of lending. Second, discrimination against certain population because of their religion or race. Third, high costs of financial services making them not feasible for financial institutions. Fourth, financial illiteracy among population. However, FI changes the structure of the financial system because of the increase of both financial transactions and customers, and risks associated with these conditions (Hannig \& Jansen, 2010). 
The concept of Financial Stability (FS) also has earned interest of academics and policymakers after the sub-prime crisis. FS is necessary for all the components of the financial system, and it has a major role in sustainable growth (Hannig \& Jansen, 2010). FS refers to the ability of the financial system to withstand shocks, and circumscribes their consequences (Creel, Hubert, \& Labondance, 2015). Several previous studies established a link between FI and FS (Neaime \& Gaysset, 2018; Siddik et al., 2018). At banks' level, even in crisis periods, low income customers maintain constant depositing and borrowing behavior. Hence, banks keep a stable base of deposits that uses in lending activities. Another way in which FI supports FS is by widening and diversifying customers' base of the financial system, and thus improving its intermediation role between savers and borrowers. Finally, FI minimizes income inequalities through bridging the gap between the poor and the rich. Thus, it is difficult to achieve financial inclusion without stability in the financial system, while it is difficult to achieve financial stability of a system that includes segments of the population excluded financially, socially and economically. On the other hand, Garcia (2016) and Mehrotra and Yetman (2015) pointed out that FI may involve risks that endanger FS through different channels. First, the participation of low-income people, which is characterized by high transaction and information costs in the financial operations, leads to the information asymmetric problem, and thus increases the inefficiency of the financial system. Second, participation of local financial institutions makes them more exposed to financial problems because of their weak governance and regulatory systems. Third, using innovative financial tools such as phone banking in the absence of supervision and regulating can threaten FS. However, since FI is in infant stage, there is growing debate about the impact of FI and FS, more empirical studies that examine this relationship are needed.

In recent years, Jordan has recognized that FI is one of the pillars of sustainable inclusive growth. Hence, in 2015, Central Bank of Jordan (CBJ), in cooperation with national and international parties, started to develop the National Financial Inclusion Strategy (NFIS), which has been launched in 2017. NFIS is based on three industry pillars, which are: microfinance, digital financial services, and small and medium sized enterprises finance. In order to facilitate the development of the pillars of NFIS, four enablers are considered, which are as follows: financial technology, financial consumer protection, data and research, and laws and regulations. The main goals of NFIS are: increasing level of FI measured by account ownership by the adult to $41.5 \%$ in 2020 , and reducing gender gap from $53 \%$ to $35 \%$. However, Jordan's interest of FI was driven by the fact the Jordanian economy needs improvement evidenced by high poverty and unemployment rates that reached $14.4 \%$, and $18.5 \%$ respectively in 2017 . In addition, according to the CBJ survey in 2017, only $33 \%$ of Jordanians have bank accounts, which reflects low level of financial inclusion.

On the other hand, maintaining FS is one of the CBJ objectives. To achieve this goal, the department of financial stability was established in the CBJ in 2013. This department is responsible for following up the implementation of the macro prudential policy that aims to control systemic risks and enhance the ability of the Jordanian financial system to face shocks. Interestingly, despite the increasing focus on FI issues, the association between FI and FS has not been studied empirically before in the Jordanian context. Therefore, this study aims to fill this important gap of knowledge. The outcome of the study will be significant for regulators and policymakers in Jordan, who developed NSFI that aims to foster FI.

\section{LITERATURE REVIEW}

The definition of FI depends on the context in which it is defined. Aduda and Kalunda (2012) mentioned that the condition of economic development and geographical location affect the definition of FI. However, despite the differences among the definitions, the Alliance for Financial
Inclusion (AFI) identifies four dimensions of FI, which are: access, usage, quality, and welfare (Alliance for Financial Inclusion, 2010). Access implies that financial services are available to all people at an affordable cost, and without strict requirements. Meanwhile, usage implies that all financial services must be appropriate to the customers, taking into consideration their financial 
knowledge and income levels. Quality relates to the efficiency of access and use of the financial services, and welfare refers to the impact of financial services on the customers' life. However, in Jordanian context, CBJ defines FI as "the process of ensuring individual and business access to various financial products and services (payment, savings, credit, transfers and insurance) in a reliable and sustainable manner" (Central Bank of Jordan, 2017, p. 7). However, Jukan and Softić (2016) used the Global Findex database to analyze the differences of the level of FI in developing regions. The results showed that the level of FI measured by five indicators in developing countries is lower than high-income countries.

Previous related literature agreed that there is no universal definition of FS. This is due to that FS has multiple dimensions, and depends on the interaction of the financial system elements (Morgan \& Pontines, 2014). The concept of FS varies between developed and developing countries. In developing countries, banks consider it as a key component of the financial system and thus, the most important determinant of the financial stability of the country. In contrast, the FS in the developed countries depends on the non-banking financial institutions such as insurance corporations and brokerage firms (Siddik et al., 2018). Garcia (2016) argued that the definition of FS commonly relates to the functions of the financial system, which are allocating savings to investments and the resistance of financial shocks. However, for the purposes of this study, FS has been defined as the ability of banks and other financial institutions to withstand financial and economic shocks.

Within a group of 49 countries, Sarma and Pais (2011) identified factors that have a significant impact on FI. They measured FI by using FI index, which captures information about three dimensions of FI, namely accessibility, availability and usage of banking services. Three regression sets were carried out to identify factors that are associated with FI. Among socio-economic variables, they found a positive relationship between FI and both GDP per capita and adult literacy, and a negative relationship with income inequality and rural population. They also found that physical infrastructure variables, such as roads, telephone and the Internet, have a significant impact on FI. As for banking sector variables, they reported a negative relationship between FI and both of non-performing assets ratio and capital asset ratio, which are measurements of the banking system soundness. Further, the results showed a negative relationship between FI and shares of foreign ownership in the total banking sector, which suggests that domestic banks contribute more to increasing the level of FI. In Bangladesh, Uddin, Chowdhury, and Islam (2017) examined factors that have a significant impact on the level of financial inclusion measured by total deposits and total loans and advances. The results showed a positive association between the level of FI and deposit interest rate, bank size and literacy rate. In addition, they reported a negative impact of loan interest rate, cost to income ratio and age dependency ratio on the level of FI.

There is a growing literature that highlights the role of FI on fostering the economic growth and financial development. Lenka and Sharma (2017) used annual time-series data during the period from 1980 to 2014 to examine the relationship between financial inclusion and economic growth measured by real GDP per capita in India. The authors used Principal Component Analysis (PCA) method to construct a comprehensive index of FI, which comprises six single indicators of FI. After controlling a set of macroeconomic variables, they found a positive relationship between FI and economic growth at both short and long run. They also reported that the type of banks' services and the availability of credit have a significant impact on FI. In Nigeria, Adeola and Evans (2017) investigated the impact of both FI and financial development on economic diversification. The results of the study showed that FI measured by financial access and financial usage has the higher significant impact on economic diversification. On the contrary, the relationship between financial development and economic diversification was found to be not statistically significant. At the cross country level, D.-W. Kim, Yu, and Hassan (2018) examined the impact of FI on the economic growth for 55 countries in Organization of Islamic Corporation. Through their study, they found a positive relationship between FI and economic growth measured by GDP per capita. On the other hand, Rasheed et al. (2016) reported a positive relationship between FI and financial development of 97 countries during the period from 2004 to 
2012. The authors measured FI through using two proxies, which are: bank branches and automated teller machine per 100,000 adults, while financial development was measured by domestic credit to private sector and stocks turnover ratio.

Indeed, there is a relative dearth of studies that link between FI and FS. Using data of eight MENA countries during the period from 2002 to 2015, Neaime and Gaysset (2018) examined empirically the effect of FI on FS, income inequality and poverty. They reported a negative relationship between FI measured by the number of banks per 100,000 adults, and income inequality, while the relationship with poverty was found to be statistically insignificant. They also found a significant and positive relationship between FI and FS measured by the standard deviation of the growth rate of deposits. The same relationship between FI and FS was found by Siddik et al. (2018), who used cross country panel data during the period of 2001-2013. They measured FI by two proxies, which are: number of SMEs borrowers to total borrowers, and ratio of outstanding SMEs loans to total loans, while they used bank Z-score as a proxy to measure FS. Morgan and Pontines (2014) investigated the impact of FI on FS using data during the period from 2004 to 2011. The results showed that an increase of lending to SMEs as a measurement of FI enhances FS through reducing bank non-performing loans and probability of defaults of financial institutions.

\section{METHODOLOGY}

\subsection{Variables and data of the study}

This study aims to examine the association between FI and FS. Thus, the dependent variable is FS. A number of proxies were used by previous scholars to measure FS, such as Z-score, standard deviation of the growth rate of deposits, non-performing loans, and probability of defaults of financial institutions. In this study, Jordanian Financial Stability Index (JFSI) was used as a measurement of FS. JFSI is an aggregate index, consists of three indices, namely banking sector index, macro economy index, and capital market index. Each index is composed by a group of indicators equal in total to 17 indicators. The methodology adopted by CBJ to measure JFSI is used widely by many countries. According to this methodology, JSFI is calculated as follows. First, the values of indicators for each index of JSFI is measured. Second, the three indices were calculated separately using the weighted average of all indicators based on their normalized form measured in the first step. Third, aggregate JFSI as the weighted average of the three indices was calculated. The value of JFSI ranges from 0 to 1 , where 0 denotes weak FS, and 1 denotes strong FS. However, data about JFSI are available on financial stability reports issued by the CBJ.

The independent variable of the study is FI. Although most of the previous studies used single indicator to measure FI, Sarma and Pais (2011) mentioned that it is preferably to use a comprehensive index that incorporates multidimensions of FI. Hence, the methodology by Sarma (2008) who developed the index of financial inclusion using three dimensions of FI was used to assess the extent of FI of 100 countries around the world. These dimensions are accessibility, availability and usage of banking services. The same dimensions were used to measure Jordanian Financial Inclusion Index (JFII). The reason behind choosing these dimensions is the availability of data needed to measure JFII during the period of study. Each dimension was measured by an indicator as shown in Table 1. Data for measuring JFII is extracted from the IMF's Financial Access Survey database (FAS), which provides annual data about indicators of financial inclusion since 2004.

Table 1. Indicators of the JFII dimension

\begin{tabular}{|c|c|}
\hline Dimension & Indicator \\
\hline Availability & $\begin{array}{l}\text { Number of branches of commercial banks } \\
\text { per } 100,000 \text { adults }\end{array}$ \\
\hline Accessibility & $\begin{array}{l}\text { Number of deposit accounts with } \\
\text { commercial banks per 1,000 adults }\end{array}$ \\
\hline Usage & $\begin{array}{l}\text { Outstanding loans with commercial banks } \\
(\% \text { of GDP) }\end{array}$ \\
\hline
\end{tabular}

Accordingly, JFII was calculated based on the following steps. First, calculating the yearly dimension index of each FI dimension for the years from 2006 to 2017 using the following formula:

$$
D I_{i}=\frac{A_{i}-\operatorname{Min}_{i}}{\operatorname{Max}_{i}-\operatorname{Min}_{i}}
$$


where $D I_{i}$ is the dimension index of dimension $i$, $A_{i}$ is the actual value of dimension $i, \operatorname{Min}_{i}$ is the minimum value of dimension $i$, and $\operatorname{Max}_{i}$ is the maximum value of dimension $i$.

Then, the yearly JFII during the period from 2006 to 2017 is measured as follows:

$J F I I=1-\frac{\sqrt{(1-A V)^{2}+(1-A C C)^{2}+(1+U S)^{2}}}{\sqrt{3}}$,

where $A V, A C C$, and US denote the dimension index for the availability, accessibility and usage dimensions, respectively. The value of JFII ranges from 0 , which indicates low FI, and 1 , which indicates high FI.

In order to isolate the impact of FI on FS, a number of control variables were used based on the literature review, namely, GDP per capita (GDPC), domestic credit to private sector as a share of GDP (DCGDP), income inequality (GINI), financial integration (FIIN), and global financial crises (GFC). GDPC is used by previous studies as a proxy of economic growth. It is expected to have a positive impact on FS. This is due to the idea that the increase in GDPC leads to an increase in FI and, thus, supports FS. A negative sign is expected to be found for DCGDP. As mentioned by Siddik et al. (2018), the higher proportion of credit to private sector could increase the financial resources to a specific sector, which leads to financial instability. In the line of Neaime and Gaysset (2018), GINI and FINN are expected to have a negative impact on FS. Babajide, Adegboye, and Omankhanlen (2015) asserted that countries with high income inequality have low FI because of unequal opportunities and monopolistic markets. These conditions could weaken FS. Neaime and Gaysset (2018) mentioned to potential explanation of the negative impact of financial integration on FS. They argued that the absence of regulatory institutions and weak control environment expand poverty and income inequality, and thus cause financial instability, especially in countries that are liberalizing their financial markets. Gini index was used to measure income inequality, and the ratio of foreign direct investment to GDP to measure financial integration. GFC variable has been used by previous scholars to investigate the relationship between global financial crisis accrued during 2007-2008 and financial stability. Since this study covers the period from 2006 to 2017 , it is worth to control the impact of global financial crisis. Hence, a dummy variable takes value 1 for the years 2007 and 2008, while it is 0 for the rest of years. Data for the control variables are retrieved from the World Banks' Global Financial Development Database (GFDD) and World Income Inequality Database (WIID).

\subsection{Empirical model}

In order to investigate the link between FI and FS in Jordan, the following empirical model was developed:

$$
F S_{t}=\gamma F I_{t}+\delta X_{t}+\mu_{t},
$$

where FS is the financial stability, and FI is the financial inclusion. $X$ denotes a vector of control variables, which are GDPC, DCGDP, GINI, FIIN, and GFC. $\mu$ is an error term, and $t$ denotes time. The study used time series data from 2006 to 2017 in Jordan, and all the variables are converted to natural logarithm in order to minimize heteroscedasticity. Table 2 summarizes the variables of the study.

Table 2. Variables of the study

\begin{tabular}{|c|c|c|c|}
\hline Variable & Abbreviation & Measurement & Source \\
\hline Financial stability & $\mathrm{FS}$ & Jordanian Financial Stability Index & Central Bank of Jordan \\
\hline Financial inclusion & $\mathrm{FI}$ & Jordanian Financial Inclusion Index & $\begin{array}{c}\text { Author's calculation based on } \\
\text { data from FAS }\end{array}$ \\
\hline GDP per capita & GDPC & Gross domestic product per capita & GFDD \\
\hline $\begin{array}{l}\text { Domestic credit to private sector } \\
\text { (\% GDP) }\end{array}$ & DCGDP & Ratio of private credit to GDP & GFDD \\
\hline Income inequality & GINI & Gini Index & WIID \\
\hline Financial integration & FIIN & $\begin{array}{l}\text { Ratio of foreign direct investment to } \\
\text { GDP }\end{array}$ & GFDD \\
\hline Global financial crisis & GFC & $\begin{array}{l}1 \text { if the year is } 2007 \text { or } 2008,0 \\
\text { otherwise }\end{array}$ & Author's compilation \\
\hline
\end{tabular}




\section{RESULTS AND DISCUSSION}

Table 3 presents the results of multicollinearity test. It can be noted that the value of Variance Inflation Factor (VIF) is less than 10, and the value of tolerance is above 0.1 , which indicates the absence of multicollinearity.

Table 3. Results of multicollinearity test

\begin{tabular}{l|c|c}
\hline \multicolumn{1}{c|}{ Variable } & VIF & Tolerance \\
\hline FI & 2.04 & 0.49 \\
\hline GDPC & 3.01 & 0.33 \\
\hdashline DCGDP & 4.59 & 0.21 \\
\hline GINI & 3.18 & 0.31 \\
FIIN & 2.00 & 0.50 \\
GFC & 2.89 & 0.35 \\
\hline
\end{tabular}

Because this study deals with time-series analysis, augmented Dickey-Fuller (ADF) unit root tests were used to determine the stationarity of the series. The results in Table 4 show that FI, GINI, and GFC are stationary at level form, while FI, GDPC, DCGDP, and FIIN are stationary at first differences. This means all variables are a combination of $\mathrm{I}(0)$ and $\mathrm{I}(1)$. Hence, fully modified ordinary least squares (FMOLS) technique is used because it considers the nature of time-series data of the study. FMOLS technique was proposed by Phillips and Hansen (1990). It was designed to modify least squares to consider the impact of serial correlation and to provide optimum estimates for co-integrating regression.

Table 4. Results of unit root test

\begin{tabular}{|c|c|c|c|c|}
\hline Variable & $\begin{array}{c}\text { ADF } \\
\text { statistics }\end{array}$ & $\begin{array}{c}\text { Critical } \\
\text { value at } \\
5 \%\end{array}$ & Probability & $\begin{array}{c}\text { Order of } \\
\text { Integration }\end{array}$ \\
\hline FS & -7.6323 & -2.8861 & 0.0000 & $\mathrm{I}(1)$ \\
\hline $\mathrm{Fl}$ & -11.1986 & -3.4861 & 0.0000 & $\mathrm{I}(0)$ \\
\hline GDPC & -7.2037 & -2.8861 & 0.0000 & $\mathrm{I}(1)$ \\
\hline DCGDP & -9.6139 & -2.8861 & 0.0000 & $\mathrm{I}(1)$ \\
\hline GINI & -9.8840 & -3.4861 & 0.0000 & $\mathrm{I}(0)$ \\
\hline FIIN & -11.1041 & -2.8861 & 0.0000 & $\mathrm{I}(1)$ \\
\hline GFC & -7.2841 & -3.4861 & 0.0000 & $\mathrm{I}(0)$ \\
\hline
\end{tabular}

In order to test the existence of stable co-integrating relations between the variables, PhilipsOuliaris test is used. According to the results in Table 5, the null hypothesis of no co-integration is rejected, which implies that there is a long relationship between the time series variables. This result supports applying the FMOLS technique.

Table 5. Results of Philips-Ouliaris test

\begin{tabular}{|c|c|c|c|}
\hline \multicolumn{4}{|c|}{ Dependent variable: D(RESID) } \\
\hline \multicolumn{4}{|c|}{ Null hypothesis: No co-integration } \\
\hline Variable & Coefficient & t-statistics & P-value \\
\hline $\operatorname{RESID}(-1)$ & -0.210 & -4.101 & 0.000 \\
\hline
\end{tabular}

The FMOLS regression results in Table 6 show that all variables have a significant impact on FS. Interestingly, a weak positive relationship was found between FI and FS. The potential explanation of this finding is that FI could imply possible risks that threaten and reduce FS. These risks resulted from the new innovative financial instruments, in addition to an increase of the participants in the financial system, such as low income customers and new providers of financial services. This argument emphasizes the role of financial supervision in reducing risk associated with expansion of unregulated members of the financial system. Another expected justification of the weak link between FI and FS is that the relationship between FI and FS is not direct.

Among control variables, GDPC has a positive and significant impact on FS. This result indicates that the higher the income at the country level, the higher FS. This result coincides with the finding of Siddik et al. (2018). Similar to the finding of Morgan and Pontines (2014), a negative and significant relationship between DCGDP and FS was found in the current article. This implies that credit provided to the private sector by banks endangers FS. The results also show a negative and significant impact of GINI on FS, implying that the higher the income inequality, the higher the likelihood of financial instability. This finding is in line with Sarma and Pais (2011). Likewise Neaime and Gaysset (2018), a negative and significant impact of financial integration on FS was found by the author of the current article. This indicates that an increase of financial integration leads to FS decrease. Finally, a negative and significant association was found between global financial crisis and FS. 
Table 6. Results of FMOLS regression

\begin{tabular}{|c|c|c|c|c|}
\hline Variable & Coefficient & $\begin{array}{c}\text { Std. } \\
\text { Error }\end{array}$ & t-statistics & Prob. \\
\hline $\mathrm{FI}$ & 0.291 & 0.137 & 1.770 & 0.080 \\
\hline GDPC & 0.324 & 0.116 & 2.236 & 0.028 \\
\hline DCGDP & -0.507 & 0.002 & -4.781 & 0.000 \\
\hline GINI & -0.480 & 0.249 & -5.842 & 0.000 \\
\hline FIIN & -0.364 & 0.123 & -2.964 & 0.005 \\
\hline GFC & -0.130 & 0.223 & -3.667 & 0.011 \\
\hline C & 0.795 & 0.076 & 3.420 & 0.001 \\
\hline R-Squared & 0.873 & & $\begin{array}{c}\text { Mean } \\
\text { dependent } \\
\text { variance }\end{array}$ & 2.001 \\
\hline $\begin{array}{l}\text { Adjusted } \\
\text { R-Squared }\end{array}$ & 0.762 & & $\begin{array}{l}\text { S. D. } \\
\text { dependent } \\
\text { variance }\end{array}$ & 0.195 \\
\hline $\begin{array}{l}\text { S. E. } \\
\text { of regression }\end{array}$ & 0.019 & & $\begin{array}{c}\text { Sum squared } \\
\text { residual }\end{array}$ & 0.005 \\
\hline $\begin{array}{l}\text { Durbin- } \\
\text { Watson } \\
\text { statistics }\end{array}$ & 2.970 & & $\begin{array}{l}\text { Long-run } \\
\text { variance }\end{array}$ & 0.001 \\
\hline
\end{tabular}

In order to generate more robust results, a different proxy of FS, which is Z-score, was used. Z-score captures the probability of default for country's banking system (Morgan \& Pontines, 2014). In addition, additional control variable was used which is the ratio of financial system deposits to GDP (FDGDP). Siddik et al. (2018) mentioned that high proportion of deposits in the financial system relative to GDP supports country's financial stability. Thus, it is expected to find a positive relationship between FDGDP and FS. Data for Z-score and FDGDP over the period from 2006 to 2017 are retrieved from GFDD.

As shown in Table 7, despite the use of different proxy of FS, the relationship between FI and FS remained positive and weak. Regarding the additional control variable, a significant and positive impact of FDGDP on FS was found. It was also found that all other control variables have a significant impact as they were in the previous model.

Table 7. Results of FMOLS regression

\begin{tabular}{|c|c|c|c|c|}
\hline Variable & Coefficient & Std. Error & t-statistics & Prob. \\
\hline $\mathrm{FI}$ & 0.225 & 0.139 & 1.935 & 0.073 \\
\hline GDPC & 0.309 & 0.124 & 2.073 & 0.044 \\
\hline DCGDP & -0.393 & 0.074 & -4.758 & 0.000 \\
\hline GINI & -0.252 & 0.032 & -3.667 & 0.000 \\
\hline FIIN & -0.101 & 0.023 & -1.965 & 0.051 \\
\hline GFC & -0.176 & 0.063 & -2.633 & 0.010 \\
\hline $\mathrm{FO}$ & 0.106 & 0.045 & 2.388 & 0.019 \\
\hline C & 0.677 & 0.043 & 8.877 & 0.000 \\
\hline R-Squared & 0.742 & & Mean dependent variance & 4.088 \\
\hline Adjusted R-Squared Square & 0.749 & & S. D. dependent variance & 0.339 \\
\hline S. E. of regression & 0.063 & & Sum squared residual & 2.755 \\
\hline Durbin-Watson statistics & 1.933 & & Long-run variance & 0.000 \\
\hline
\end{tabular}

\section{CONCLUSION}

In the last years, the concept of inclusive and sustainable growth has received considerable attention in both developing and developed countries. In parallel, national and international policymakers have recognized the importance of financial inclusion as a tool to achieve the targeted growth. In response to these developments, the Central Bank of Jordan has announced the National Strategy for Financial Inclusion in 2017. On the other hand, financial stability is considered a priority for policy makers around the world. Previous studies have argued that financial inclusion contributes to the strengthening of the financial stability of the country. Indeed, the relationship between financial inclusion and financial stability has not been studied empirically in Jordanian context. Thus, this study aims to answer the question regarding the existence of the relationship between financial inclusion and financial stability.

Using annual data of selected financial inclusion indicators, Jordanian financial inclusion index was computed to assess the level of financial inclusion in Jordan during the period from 2006 to 2017. The 
results of the study support the point of view that assumes a significant and positive impact of financial inclusion on financial stability measured by Jordanian financial stability index. Based on the findings, this study recommends supervising authorities to follow prudent and adequate supervisory standards that manage risk associated with expansion of the participants of the financial system. In addition, it is necessary to increase financial awareness for all sectors in Jordanian society through financial teaching, which enhances the use of financial services and helps participants to manage their saving and take the right investment decisions.

For control variables, a positive relationship was found between GDP per capita and financial stability. On the contrary, domestic credit to private sector, income inequality, financial integration and global financial crisis have a significant and negative impact on financial stability.

Short series of data in addition to missing data are the main challenges that faced the study. These limitations prevented the use of more indicators to develop a comprehensive index of financial inclusion. Upon the availability of the data, future studies can incorporate additional financial inclusion indicators to construct a more comprehensive index of financial inclusion. In addition, future studies can investigate the link between financial inclusion and other variables such as poverty and income inequality, and thus deepen the understanding of this important issue.

\section{ACKNOWLEDGMENT}

This paper is supported by the Deanship of Scientific Research and Graduate Studies at Philadelphia University in Jordan.

\section{REFERENCES}

1. Adeola, O., \& Evans, O. (2017).

Financial inclusion, financial development, and economic diversification in Nigeria. The Journal of Developing Areas, 51(3), 1-15. Retrieved from https://ro.uow.edu. au/aabf/vol12/iss1/3/

2. Aduda, J., \& Kalunda, E. (2012). Financial inclusion and financial sector stability with reference to Kenya: A review of literature. Journal of Applied Finance and Banking, 2(6), 95. Retrieved from http:// www.scienpress.com/Upload/ JAFB/Vol\%202_6_8.pdf

3. Alliance for Financial Inclusion. (2010). Financial Inclusion Measurement for Regulators: Survey Design and Implementation. Policy paper, Data Working Group, AFI, Bangkok. Retrieved from https:// www.afi-global.org/sites/default/ files/afi_policypaper_datameasurement_en.pdf

4. Babajide, A. A., Adegboye, F. B., \& Omankhanlen, A. E. (2015).
Financial inclusion and economic growth in Nigeria. International Journal of Economics and Financial Issues, 5(3), 629-637. Retrieved from http://eprints.covenantuniversity.edu.ng/5426/\#.W8IosfZuI2x

5. Central Bank of Jordan. (2017). Financial Inclusion Diagnostic Study in Jordan. Amman: CBJ. Retrieved from http://www.cbj. gov.jo/EchoBusv3.0/SystemAssets/ PDFs/2018/Financial\%20Inclusion\%20Diagnostic\%20Study\%20 in\%20Jordan\%202017.pdf

6. Creel, J., Hubert, P., \& Labondance, F. (2015). Financial stability and economic performance. Economic Modelling, 48, 25-40. https://doi.org/10.1016/j.econmod.2014.10.025

7. García, M. J. R. (2016). Can financial inclusion and financial stability go hand in hand? Economic Issues, 21(2), 81-103. Retrieved from http://www.economicissues.org.uk/ Files/2016/216Garcia.pdf
8. Hannig, A., \& Jansen, S. (2010). Financial inclusion and financial stability: Current policy issues (ADBI working paper series, No. 259). Retrieved from https://www. adb.org/publications/financialinclusion-and-financial-stabilitycurrent-policy-issues

9. Jukan, M. K., \& Softić, A. (2016). Comparative analysis of financial inclusion in developing regions around the world. Economic Review: Journal of Economics and Business, 14(2), 56-65. Retrieved from http://ef.untz.ba/wp-content/ uploads/2017/03/ER_November_2016_5-1.pdf

10. Kim, D.-W., Yu, J.-S., \& Hassan, M. K. (2018). Financial inclusion and economic growth in OIC countries. Research in International Business and Finance, 43, 1-14. https://doi.org/10.1016/j. ribaf.2017.07.178

11. Kim, J.-H. (2016). A study on the effect of financial inclusion 
on the relationship between income inequality and economic growth. Emerging Markets Finance and Trade, 52(2), 498-512. https://doi.org/10.1080/154049 6X.2016.1110467

12. Lenka, S. K., \& Sharma, R. (2017) Does financial inclusion spur economic growth in India? The Journal of Developing Areas, 51(3), 215-228. https://doi.org/10.1353/ jda.2017.0069

13. Mehrotra, A., \& Yetman, J. (2015). Financial inclusion-issues for central banks. BIS Quarterly Review, 83-96. Retrieved from https:// papers.ssrn.com/sol3/papers. cfm?abstract_id=2580310

14. Morgan, P. J. \& Pontines, V. (2014). Financial Stability and Financial Inclusion (ADBI working paper No. 488). Retrieved from https://www. adb.org/sites/default/files/publication/154225/adbi-wp488.pdf

15. Neaime, S., \& Gaysset, I. (2018). Financial inclusion and stability in MENA: Evidence from poverty and inequality. Finance Research Letters, 24, 230-237. https://doi. org/10.1016/j.frl.2017.09.007

16. Phillips, P. C. B., \& Hansen, B. E. (1990). Statistical inference in instrumental variables regression with I(1) processes. The Review of Economic Studies, 57(1), 99-125. https://doi.org/10.2307/2297545

17. Rasheed, B., Law, S.-H., Chin, L., \& Habibullah, M. S. (2016). The Role of Financial Inclusion in Financial Development: International Evidence. Abasyn University Journal of Social Sciences, 9(2), 330-348. Retrieved from http://ajss.abasyn.edu. pk/wp-content/uploads/2016/12/ AJSS-9-2-RP2.pdf

18. Sarma M. (2008). Index of financial inclusion (ICRIER working paper No. 215). Retrieved from http://icrier.org/pdf/Working_Paper_215.pdf

19. Sarma, M., \& Pais, J. (2011). Financial inclusion and development.
Journal of International Development, 23(5), 613-628. https://doi. org/10.1002/jid.1698

20. Siddik, M., Alam, N., \& Kabiraj, S. (2018). Does Financial Inclusion Induce Financial Stability? Evidence from Cross-Country Analysis. Australasian Accounting, Business and Finance Journal, 12(1), 34-46. http://dx.doi. org/10.14453/aabfj.v12i1.3

21. Uddin, A., Chowdhury, M. A. F., \& Islam, M. N. (2017). Determinants Of Financial Inclusion In Bangladesh: Dynamic Gmm \& Quantile Regression Approach. The Journal of Developing Areas, 51(2), 221-237. https://doi. org/10.1353/jda.2017.0041

22. Zins, A., \& Weill, L. (2016). The determinants of financial inclusion in Africa. Review of Development Finance, 6(1), 46-57. https://doi.org/10.1016/j. rdf.2016.05.001 